\title{
Construction and validation of the Adult Stressors Inventory (ASI)
}

\author{
Construção e validação do Inventário de Estressores para Adultos (IE)
}

\author{
Paulo Eduardo Benzoni ${ }^{1}$ (D)
}

\begin{abstract}
Introduction: A great deal of research has been conducted all over the world into stress and its impacts on the health of populations.

Objective: To develop and validate an instrument for identification of the principal stressors and their magnitude in people who are subject to stress.

Method: The instrument was constructed on the basis of analysis of 20 interviews conducted with 10 male and 10 female adults with stress according to the Perceived Stress Scale. A total of 46 statements were derived from this analysis, referring to stressful situations in different areas of life. Each statement is evaluated on a Likert response scale indicating the degree of impact and the respondent's ability to deal with the stressor it describes. The instrument was validated with a non-probabilistic sample comprised 450 adults, aged from 18 to 65 years, $62.7 \%$ women and $37.3 \%$ men, who completed the instrument and also the Perceived Stress Scale, to enable criterion validation.

Results: Exploratory factor analysis identified 42 valid items and grouped them into eight factors that explained $64.5 \%$ of total variance. These factors were financial stressors; working environment stressors; cognitive and behavioral stressors; family environment stressors; health status stressors; stressors related to conditions for relaxation; workload-related stressors; and social relationship stressors. Cronbach's alpha for the instrument was 0.94. A relationship was observed between the newlydeveloped inventory and the Perceived Stress Scale, providing grounds for accepting the validation hypothesis.

Conclusions: The results were psychometrically satisfactory and made possible provision of a new instrument for stress interventions, with advantages over other instruments.
\end{abstract}

Keywords: Stress, stressors, psychological assessment.
Resumo

Introdução: Muitas pesquisas têm sido realizadas sobre o estresse e seus impactos na saúde das populações.

Objetivo: Desenvolver e validar um instrumento para identificação dos principais estressores e sua magnitude em pessoas com estresse.

Método: $O$ instrumento foi construído a partir da análise de 20 entrevistas realizadas com adultos apresentando estresse de acordo com a Escala de Percepção de Estresse (10 homens e 10 mulheres). Um total de 46 afirmativas derivaram desta análise, referindo-se a situações estressantes em diferentes áreas da vida. Cada afirmativa foi avaliada em uma escala do tipo Likert, indicando o grau de impacto e a capacidade do respondente de lidar com o estressor descrito. A validação foi realizada com amostra não probabilística de 450 adultos, com idades entre 18 e 65 anos, $62,7 \%$ mulheres e $37,3 \%$ homens, que responderam o instrumento e a Escala de Percepção de Estresse, permitindo a validação do critério.

Resultados: A análise fatorial exploratória identificou 42 itens válidos e os agrupou em oito fatores que explicaram $64,5 \%$ da variância total. Esses fatores foram estressores financeiros; do ambiente de trabalho; cognitivos e comportamentais; do ambiente familiar; do estado de saúde; relacionados a condições de relaxamento; relacionados à carga de trabalho; e estressores dos relacionamentos sociais. O alfa de Cronbach para o instrumento foi de 0,94, e observou-se relação entre o inventário desenvolvido e a Escala de Percepção de Estresse, possibilitando a aceitação da hipótese de validação.

Conclusões: Os resultados foram psicometricamente satisfatórios e possibilitaram a disponibilização de um novo instrumento para intervenções de estresse.

Descritores: Estresse, estressores, avaliação psicológica.

\footnotetext{
${ }^{1}$ Grupo de Pesquisas em Saúde Mental nos Contextos Institucionais, Universidade Paulista (UNIP), Ribeirão Preto, SP, Brazil. Submitted Sep 17 2018, accepted for publication Mar 282019.

Suggested citation: Benzoni PE. Construction and validation of the Adult Stressors Inventory (ASI). Trends Psychiatry Psychother. 2019;41(4):375-386. http://dx.doi.org/10.1590/2237-6089-2018-0079
} 


\section{Introduction}

Stress was first conceptualized by Hans Selye, who described it as the general adaptation syndrome. ${ }^{1}$ This syndrome consists of an organism's neuropsychophysiological response to events that could endanger its physical and psychological integrity and is characterized as a biological self-preservation mechanism. ${ }^{2}$ Manifestation occurs in phases; an initial transitory stress, of low or high intensity, may progress to a state of deterioration that debilitates the immune system, at which point serious diseases may begin to emerge. ${ }^{3-7}$ Several different studies have identified the presence of stress as a contributing factor in dermatological diseases ${ }^{8}$ cardiovascular diseases, ${ }^{9,10}$ and fibromyalgia, ${ }^{11}$ and its role in mental disorders has also been demonstrated. 12

The stress response and the concept of homeostasis deal with the same phenomenon, i.e., the ways that organisms regulate and adjust in response to challenges. However, the concept of homeostasis extends to that of allostasis, in which the response to stressor stimuli varies as a function of the degree of predictability, of the intensity, of the duration, and of the nature of the stressor stimulus. The response also involves subjective aspects such as the individual's expectations with relation to the challenges faced. These challenges activate homeostatic systems that initiate actions for regulation at more elevated levels of demand, to achieve a state known as allostasis. ${ }^{13,14}$ Allostasis is a state of organic equilibrium that is set up in response to the level of environmental demands and the individual's assessment of them. This assessment is responsible for differences between different individuals responses to the same stressors.

The stimulus that elicits stress is called a "stressor" and is understood as an environmental event that significantly disturbs an individual's dynamics, provoking a state of alert and altering their physiological equilibrium. ${ }^{3}$ A stressor can be defined as a potential threat that is unpredictable, uncontrollable, or unavoidable, challenging the individual to react and provoking physiological and behavioral responses. ${ }^{4}$ The interindividual differences in responses to a stressor are manifest in the degree of impact it causes, which is determined by characteristics of the stimulus and by the organism's ability to deal with the situation. This, in turn, is the result of individual factors such as sex, age, temperament, and cognition, of the controllability of the stressor, and of social factors, such as social role and/or social support. ${ }^{14-16}$

On the cognitive level, the response to the stressor is filtered according to the vulnerability of the person who will process the information and evaluate the situational aspects and to the stimuli presented as a result of it and which emotion will be elicited in response. The executive functions of the brain therefore play a moderating role in the response to stress. ${ }^{17}$ The executive functions are primarily found in the prefrontal cortex and when a stimulus is perceived as stressful, these regions are activated and modulate the response to the stimulus by means of metacognitive processes. The lower the functional level of the executive functions, the stronger the response exhibited to the stressor will be, illustrating that metacognition plays an important role in regulation of the response to stress. ${ }^{17}$

Metacognition refers to a person's knowledge and awareness of their own cognitive systems and the factors that can affect these systems. ${ }^{18}$ Working from this concept, researchers have identified a positive correlation between metacognition and perception of stress, anxiety, and depression. ${ }^{19}$ Furthermore, Emotional Intelligence 20 acts on metacognitive processing. For example, a study that investigated the relationship between dimensions of emotional intelligence and reactivity to negative stressors found that individual differences in adaptation to negative stressors can be attributed to aspects of emotional intelligence, since the anxiety experienced in response to stressors proved to be weaker for participants with higher level of self-awareness, expression, selfcontrol, and emotional self-control. ${ }^{21}$ Stressful events cannot therefore be attributed the same magnitude for everybody, because the reactions to them will differ from one individual to another.

There are, therefore, interactions between neurological, physiological, and social factors in the response to stress which, when combined, generate a diversity of responses with interindividual variations in terms of intensity, form, and expression. This is at the foundation of the issue that a given stressor may have a greater or smaller impact on one person than on another and so, although they do have some objective qualities, it can be difficult to quantify stressors because of people's subjective perception of them. ${ }^{3}$

The most widely known of the many instruments for measuring stress was developed by Holmes \& Rahe in the 1970s and has been used in more than 10,000 published studies over the past 40 years. ${ }^{22}$ Holmes \& Rahe analyzed a considerable number of clinical cases and correlated diseases with events in the previous year of patients' lives. Their Social Readjustment Rating Scale, better known as the Holmes Scale, contained 43 items relating to professional, family, social, and financial life and organized each item according to the degree of its impact on the person, i.e. according 
to its stress load. ${ }^{23}$ These events comprised a list of universal stressful events ordered from the item with the greatest impact, death of a spouse, in first place, to minor violation of law, in last place. While the scale has been widely adopted, it has also been the subject of certain criticisms.

One study tested the relationship between the Social Readjustment Rating Scale and instruments that measure risk factors for psychopathologies, observing that when the episodes indicated on the scale were probed, there was a very large variation from person to person. ${ }^{22}$ For example, an item asking whether the respondent has had a serious illness during the past year could be taken as referring to diseases ranging from cancer to the flu, because analysis was being influenced by each respondent's subjectivity, resulting in a large degree of variability between the responses of the people surveyed. Thirty years after the scale's creation, the impacts of the life events it lists were re-evaluated and it was found that some of them, such as dismissal from work, marital reconciliation, business readjustment, and retirement, had reduced, which, because of its underlying model, changed the instrument's results. ${ }^{24}$

Many other instruments for measurement of stress have been developed and validated. The most widely used in Brazil is the Lipp Adult Stress Symptoms Inventory, known as the ISSL, ${ }^{25}$ which is a set of three lists of symptoms of stress. Depending on the number and types of symptoms endorsed on each list, it is possible to determine whether the respondent is suffering from stress and, if so, at what intensity. Another widely-used instrument is the Perceived Stress Scale (PSS), which was created by Cohen et al. ${ }^{26}$ and has been culturallyadapted for Brazil. ${ }^{27}$ This is a self-report measure comprising 10 positive and negative statements about life situations, to which the subject provides responses grading the extent that each situation upset them.

With regard to assessment of stressors, several instruments have been developed for specific situations, such as occupational stressors, ${ }^{28,29}$ stressors in the context of employment, ${ }^{30}$ and stressful life events. ${ }^{31}$ However, the instruments currently available are either limited to specific areas of stressors or they are of limited scope and no single instrument encompasses broader aspects of stress generation in the individual.

When dealing with a person who is showing signs of stress, knowing what the main sources of stress are can enable planning of more focused treatment strategies. The objective of this study was thus to develop an instrument, based on the concept of stress developed by Selye ${ }^{1,2}$ and the concept of stressors as proposed by Franklin et al., ${ }^{4}$ that would be able to identify which domains of a person's life are actually contributing to development and/or maintenance of the stress exhibited, identifying the magnitude and power of the stressor for that specific respondent, thereby extending the possibilities for more specific and effective interventions to treat it.

\section{Method}

The protocols for development and validation of the scale were approved by the ethics committee at Universidade Paulista (CAAE 66057317.3.0000.5512, protocols 2.062.961 and 2.378.286).

The description of this project will also be organized in two stages; the process of development of the inventory first, followed by the process for its validation.

\section{Development}

Since development of a construct implies definition of the trait that the instrument is intended to measure, development of this instrument was based on conceptual, neuropsychological, and neurophysiological theories of the stress process. 2,13,17,18,21,32 Of these, Selye's ${ }^{1,2}$ concept of stress and Franklin et al.'s ${ }^{4}$ concept of stressors provide the primary theoretical foundation.

A qualitative approach was chosen for this process, because it was considered the most appropriate way to understand the manifestations of the phenomenon of stress in loco and in depth. ${ }^{33,34}$ Data were collected during semi-structured interviews that followed a loose script. This method enables a fluid conversation, which in turn allows relevant issues to be explored in further depth as they emerge during the conversation.

The literature indicates that the type and magnitude of stressors differ according to a series of variables. The most significant of these are age and sex. Starting with these variables, a total of 20 semi-structured interviews were conducted, audio recorded, and transcribed verbatim. Twenty adults were recruited for this stage, 10 women, from 25 to 61 years old, and 10 men, from 24 to 57 years old. All of them exhibited signs of stress according to Cohen et al.'s ${ }^{26}$ Perceived Stress Scale (PSS), the version culturally-adapted and validated in Brazil by Reis et al. ${ }^{27}$ The PSS was chosen because it is one of the most widely-used instruments in the international literature on stress.

The free-floating reading content analysis technique was used to seek manifest and latent meanings in the information contained in the interview transcripts. Taking a clinical-qualitative view, ${ }^{33}$ the objective was to understand the dynamics of manifestation and maintenance of stress in the interviewees. During the reading process, information was compiled and 
manifestations of theoretical constructs related to the dynamics of stress were noted, thereby generating the analytical categories. ${ }^{35}$ These categories were defined with reference to the scientific literature on the subject, in counterpoint to the content expressed in the interviews and were defined, by domain, as follows: family life; social life; professional life; health; financial; and cognitive. Initially, the interviewees' utterances were classified by category and then, after they had been read and organized, the subcategories listed in Table 1 were extracted.
The utterances were then reorganized by subcategory, producing the statements to be used as items on the instrument in development. For example, in the family domain, marital life subcategory, the statement used was "My marriage/romantic relationship is not going well." A total of 46 statements were compiled, comprising the items of the version of the Adult Stressors Inventory (ASI) instrument used for validation. The statements/items were all constructed with the characteristics of an "event" that provokes stress, according to the literature..$^{3,4}$

Table 1 - Categories and subcategories extracted during analysis of interviews.

\begin{tabular}{|c|c|}
\hline Category & Subcategories \\
\hline Stressors in the family life domain & $\begin{array}{l}\text { Marital life } \\
\text { Changes to family arrangements } \\
\text { Loss of family member/bereavement } \\
\text { Chronic health problem in the family } \\
\text { Financial problems in the family } \\
\text { Conflict in respondent's relationship with family } \\
\text { Conflict in intrafamily relationships in general } \\
\text { Overloaded by family workload }\end{array}$ \\
\hline Stressors in the social life domain & $\begin{array}{l}\text { Quality of social relationships } \\
\text { Loneliness } \\
\text { Lack of social life }\end{array}$ \\
\hline Stressors in the professional life domain & $\begin{array}{l}\text { High level of responsibility at work } \\
\text { Unhealthy atmosphere at work } \\
\text { Under pressure to perform and deliver at work } \\
\text { Competition at work } \\
\text { Physical working conditions } \\
\text { Demotivated at work } \\
\text { Inconsistent people management at work } \\
\text { Time management at work } \\
\text { Relationship with customers } \\
\text { Relationship with superiors } \\
\text { Interpersonal relationships at work } \\
\text { Overload at work } \\
\text { Tedious, repetitive work }\end{array}$ \\
\hline Stressors in the health domain & $\begin{array}{l}\text { Health care } \\
\text { Health worries } \\
\text { Problems sleeping } \\
\text { Chronic health problems/pains } \\
\text { Quality of sleep } \\
\text { Quantity of sleep } \\
\text { Overload }\end{array}$ \\
\hline Stressors in the financial domain & $\begin{array}{l}\text { Finances out of control } \\
\text { Shortage of money } \\
\text { Limited spending power } \\
\text { Financial limitations }\end{array}$ \\
\hline Stressors in the cognitive domain & $\begin{array}{l}\text { Anxiety } \\
\text { Impatience } \\
\text { Irritability } \\
\text { Omnipotence } \\
\text { Personal organization } \\
\text { Worries about the future } \\
\text { Psychological rumination }\end{array}$ \\
\hline
\end{tabular}


Since stress involves an interpretation of the magnitude of the stressor and the individual's capacity to deal with it, a set of responses was created along a scale from 0 (zero) to 4 (four), as follows: 0 - This does not apply to me; 1 - It is true, but I managed to resolve it easily; 2 - It is true, it was a bit difficult, but I'm managing to resolve it; 3 - It is true and difficult to resolve, and 4 - It is totally true and I have not been able to resolve it. The objective of this response scale was to give respondents the chance to indicate the degree of perceived impact and their capacity to deal with the stressor. Finally, it was decided to organize the 46 statements on the instrument into six groups, based on their categories, and to request the respondent to evaluate each statement on the basis of the preceding 6 months.

To verify the semantic structure of the instructions, response scale, and statements, a pilot model of the instrument was administered to a group of ten people with different educational levels, chosen at random, who completed it and then indicated possible sources of any difficulties that they had encountered when undertaking the task.

During this pilot study, it was observed that the response scale was confusing because the constructions "does not apply to me" and "is true, but..." were not compatible with the respondents' experiences. The response scale was therefore rewritten as follows: 0 - This is not happening; 1 - This has happened, but I can deal with it easily; 2 - This has happened and it is a little difficult, but I can deal with it; 3 - This has happened and I am finding it hard to deal with, and 4 - This has happened and I am unable to deal with it. The aim of these alterations was to improve respondents' ability to indicate the degree of perceived impact and their capacity to deal with the stressor. After the statements, response scale, and instructions had been modified, the instrument was in the final format used for the validation study.

\section{Validation}

Validation was conducted with a non-probabilistic convenience sample comprising 450 adults of both sexes aged from 18 to 65 who were residents of the metropolitan zone of Ribeirão Preto, in upstate São Paulo, Brazil. Data were collected during the period between March and June of 2018 by a team of Psychology students. These research assistants underwent training including learning about the study's theoretical foundations and instruction on how to administer the instrument and how to identify subjects who fit the desired profile.

The participants invited to take part in the study were informed about the research objectives and its implications and procedures, and about any risks to which they could be exposed. This was achieved using a free and informed consent form. Those who agreed to take part signed two copies of the consent form and data collection was begun. First, a questionnaire was administered to collect sociodemographic data for categorization, then the PSS was administered, to identify the degree of perceived stress, and, finally, the ASI was administered.

Data collection was started with a pilot sample of 30 participants who met the inclusion criteria. This pilot study was conducted to test the linguistic adequacy of the instrument and to provide data for a pre-test to identify whether it was meeting the criterion of differentiation of the areas measured; thereby creating an opportunity for correction of biases before administration to the definitive sample. None of the participants from the pilot study were included in the final sample used for validation.

The final validation sample comprised $62.7 \%$ women and $37.3 \%$ men. The criterion adopted to stratify age in groups that could best classify stressors by phases of life was to define age groups on the basis of an adaptation of the stages of the lifecycle proposed in the literature. ${ }^{36}$ These were defined as end of adolescence, from 18 to $24,31.1 \%$ of the sample, young adulthood, from 25 to $39,40.4 \%$ of the sample, middle age, from 40 to $64,27.3 \%$ of the sample, and seniors, over the age of 65 , accounting for $1.1 \%$ of the sample. Almost half of the sample, $45.3 \%$, were residents of the city of Ribeirão Preto and the remainder of the sample lived in 28 towns in the Ribeirão Preto metro area. With regard to marital status, $50.9 \%$ were married and $37.6 \%$ were single, while $7.3 \%$ were separated. More than half of the sample, $56 \%$, did not have children and $34.2 \%$ had one or two children. The most common educational level was secondary education completed, at $43.3 \%$, while $24.7 \%$ had graduated from higher education.

\section{Analysis}

The results of the PSS were analyzed as recommended by its authors and sociodemographic data were analyzed using descriptive statistics to plot the profile of the sample investigated.

The internal consistency of the instrument (ASI) was analyzed by calculating Cronbach's alpha and by conducting exploratory factor analysis with varimax rotation and Kaiser normalization, according to psychometric principles. ${ }^{37-40}$ These calculations were performed using the Statistical Package for the Social Sciences (SPSS) version 21. The final working sample comprised 450 participants and the instrument contained 46 items, the equivalent of 9.8 participants per item, which is considered ideal in the 
literature. ${ }^{41}$ This analysis was used to identify the items that were most appropriate from a statistical perspective, which were used in the final version of the instrument.

The analysis of validity was conducted using criterion validation, consisting of raising a hypothesis and testing it using another, validated, instrument the PSS. The PSS was chosen because it is a brief and consistent instrument that is widely used in scientific studies in this area. The validation hypothesis was as follows: "For an instrument that evaluates stressors to be valid, the perceived degree of magnitude of the stressor, as measured by the instrument, should follow the degree of magnitude of stress measured by a different, validated, instrument." This hypothesis is based on the concepts of stress, including its process and forms of manifestation, ${ }^{2,3}$ and of stressors, as set out in the literature. ${ }^{4}$ In order to test this hypothesis, the data obtained using the PSS were related to those obtained using the newly-developed instrument. Since there are no normative parameters for classification of PSS results and since its results exhibited a normal distribution in this study, they were divided into quartiles and participants whose results fell within the third and fourth quartiles were defined as having high stress levels. Using ANOVA, it was then possible to test the validity of the new instrument against overall PSS results and against PSS result quartiles.

\section{Results}

Cronbach's alpha calculated for the PSS was 0.85 and Cronbach's alpha for the ASI, in its original 46-item form, was 0.94.

Exploratory factor analysis with varimax rotation was used to investigate the distribution of ASI items. The Kaiser-Meyer-Olkin test of sampling adequacy for factor analysis was 0.92 , with a significance level of $p \leq$ 0.001 . The results of the first exploratory factor analysis, with 46 items, identified a structure comprising nine factors with Eigenvalues exceeding 1 . Together, these factors explained $63.5 \%$ of variance. Four items were then excluded on the basis that their factor loadings and adequacy indicated that they did not fit the construct, since their factor loadings were below 0.4 ("My relatives' health has been worrying me") or because they did not fit the subject of the factor they had been assigned to ("My marriage/romantic relationship is not going well; Family members have died, which shook me" and "It is very difficult to deal with some clients at work").

Factor analysis was conducted once more with the remaining 42 items and this analysis identified eight factors with Eigenvalues greater than 1 that explained
$64.5 \%$ of total variance. The rotational component matrix is shown in Table 2. Observing the content of the items that were grouped onto each factor, it was clear that they dealt with themes in common and these were used to name each of the factors, which became groups of items on the instrument (Table 3).

Cronbach's alpha for the entire 42-item instrument was 0.94 and none of the factors had an alpha value of less than 0.8 (Table 3 ). Table 4 lists the final set of items, with their respective factor loadings.

In order to test the hypothesis raised for criterion validation, it was necessary to identify those participants with the highest degree of stress according to the PSS and, since there are no normative data for this scale derived from the Brazilian population, the decision was taken to divide the sample into quartiles, which provided an intragroup criterion. It was assumed that the higher the quartile, the higher the person's perceived stress level. ANOVA was conducted for the variance between overall and factor results from the ASI against the PSS quartiles. The majority of factors exhibited significant differences with $p \leq 0.05$ when paired against PSS quartiles. Only the second and third quartile pair, which represents a "middle zone," were related to fewer factors with significant differences. The means for total ASI score and by factors against each PSS quartile exhibited an ascending progression, in line with the trend of PSS results (Table 5).

It is believed that, since as the perception of stress increases, the perception of the intensity and magnitude of the stressors also increases, then the ASI has the sensitivity to measure these stressors, which confirms the validation hypothesis.

\section{Discussion}

The process of validation of a psychological instrument starts with formulation of detailed definitions of the trait or construct that it is intended to measure, which are derived from the theory on the subject, from earlier research, or from systematic observation and analysis of the behavioral domain that it belongs to. ${ }^{38}$ Thus, the process to develop the Adult Stressors Inventory (ASI) is derived not only from the psychological theory that defines the construct of "stressors,"1,3,4 but also from a systematic process of observation and analysis of the behavioral domain that encompasses it.

The statements that comprise the ASI items originated from analysis of the content ${ }^{35}$ of interviews with adults who were exhibiting stress, which revealed the occurrence of stressors in five areas of life that proved to be stress-provoking: finances, work, social 
relationships, family, and health. Additionally, the analysis revealed cognitive factors that appear to interfere with generation and maintenance of stress. The areas identified in the interviews can be referred to as stress generation domains and are in line with what is found in the literature on stress and stressors. ${ }^{5-7,42}$

When formulating the items for the ASI, care was taken to ensure that they portrayed daily problems that could refer to "dangers" to the life of the person to whom the instrument is being administered and constituted stressors as conceptualized in the literature, ${ }^{1,3,4,42}$ comprising life events, chronic demands, and day-to-day irritations. ${ }^{42}$ Additionally, the literature identifies internal stressors as types of cognition $17,19,21,43$ that predispose people to development of a state of stress. A sixth domain was therefore formulated, initially entitled "cognition," which contained statements referring to thoughts and behaviors that predispose a person to stress.

Table 2 - Varimax rotation component matrix for 42 items from the Adult Stressors Inventory (ASI) administered to 450 participants.

\begin{tabular}{|c|c|c|c|c|c|c|c|c|}
\hline Item & Factor 1 & Factor 2 & Factor 3 & Factor 4 & Factor 5 & Factor 6 & Factor 7 & Factor 8 \\
\hline 2 & 0.552 & 0.106 & 0.149 & 0.267 & 0.127 & 0.137 & 0.051 & 0.165 \\
\hline 10 & 0.864 & 0.073 & 0.136 & 0.122 & 0.024 & 0.066 & 0.095 & 0.024 \\
\hline 11 & 0.774 & 0.081 & 0.152 & 0.161 & 0.079 & 0.038 & 0.122 & -0.023 \\
\hline 12 & 0.826 & 0.042 & 0.226 & 0.095 & 0.019 & 0.048 & 0.026 & 0.100 \\
\hline 13 & 0.882 & 0.059 & 0.136 & 0.105 & -0.005 & 0.067 & 0.047 & 0.051 \\
\hline 14 & 0.841 & 0.159 & 0.150 & 0.104 & -0.025 & 0.143 & 0.020 & 0.069 \\
\hline 15 & 0.702 & 0.179 & 0.073 & 0.131 & 0.046 & 0.097 & 0.015 & 0.023 \\
\hline 18 & 0.030 & 0.732 & 0.081 & 0.019 & 0.076 & 0.083 & 0.180 & 0.059 \\
\hline 19 & 0.101 & 0,757 & 0.111 & 0.007 & 0.082 & 0.070 & 0.265 & -0.011 \\
\hline 21 & 0.093 & 0.661 & 0.151 & 0.058 & 0.041 & 0.015 & 0.154 & -0.008 \\
\hline 22 & 0.110 & 0.641 & -0.011 & 0.043 & 0.103 & 0.026 & 0.243 & 0.035 \\
\hline 24 & 0.040 & 0.526 & 0.072 & 0.126 & 0.001 & 0.153 & -0.072 & 0.196 \\
\hline 25 & 0.073 & 0.697 & 0.070 & 0.082 & 0.105 & -0.045 & 0.134 & 0.068 \\
\hline 26 & 0.111 & 0.619 & 0.172 & 0.071 & 0.084 & -0.050 & 0.064 & 0.129 \\
\hline 27 & 0.105 & 0.723 & 0.108 & 0.080 & -0.028 & 0.147 & 0.095 & 0.027 \\
\hline 40 & 0.129 & 0.098 & 0.711 & 0.105 & 0.143 & 0.118 & 0.107 & 0.164 \\
\hline 41 & 0.052 & 0.225 & 0.737 & 0.203 & 0.032 & 0.161 & -0.015 & 0.091 \\
\hline 42 & 0.390 & 0.135 & 0.570 & 0.220 & 0.194 & 0.155 & 0.062 & 0.226 \\
\hline 43 & 0.258 & 0.034 & 0.567 & 0.118 & 0.193 & 0.082 & 0.315 & 0.194 \\
\hline 44 & 0.218 & 0.225 & 0.688 & 0.238 & 0.150 & 0.176 & -0.023 & 0.140 \\
\hline 45 & 0.193 & 0.121 & 0.723 & 0.041 & 0.134 & 0.162 & 0.011 & 0.056 \\
\hline 46 & 0.250 & 0.127 & 0.649 & 0.126 & 0.069 & 0.160 & 0.165 & 0.062 \\
\hline 4 & 0.134 & 0.093 & 0.169 & 0.780 & 0.089 & 0.065 & -0.087 & 0.074 \\
\hline 5 & 0.141 & 0.132 & 0.091 & 0.736 & 0.116 & 0.127 & -0.026 & 0.127 \\
\hline 6 & 0.244 & 0.024 & 0.092 & 0.595 & 0.036 & 0.008 & 0.199 & 0.120 \\
\hline 7 & 0.154 & 0.132 & 0.184 & 0.789 & 0.069 & 0.052 & 0.042 & 0.074 \\
\hline 8 & 0.165 & 0.037 & 0.130 & 0.660 & 0.080 & 0.098 & 0.205 & 0.068 \\
\hline 29 & 0.058 & 0.073 & 0.143 & 0.185 & 0.844 & 0.101 & 0.040 & 0.102 \\
\hline 31 & 0.043 & 0.097 & 0.189 & 0.141 & 0.839 & 0.174 & 0.021 & 0.150 \\
\hline 33 & 0.090 & 0.095 & 0.230 & 0.020 & 0.562 & 0.362 & 0.016 & 0.041 \\
\hline 36 & 0.007 & 0.137 & 0.078 & 0.043 & 0.794 & 0.198 & 0.020 & -0.002 \\
\hline 30 & 0.149 & 0.161 & 0.259 & 0.093 & 0.257 & 0.757 & -0.007 & 0.154 \\
\hline 32 & 0.158 & 0.110 & 0.235 & 0.108 & 0.139 & 0.838 & 0.096 & 0.094 \\
\hline 34 & 0.142 & 0.152 & 0.310 & 0.097 & 0.320 & 0.637 & 0.176 & 0.049 \\
\hline 35 & 0.130 & -0.024 & 0.118 & 0.117 & 0.195 & 0.758 & 0.148 & 0.105 \\
\hline 17 & 0.061 & 0.488 & 0.146 & 0.007 & 0.086 & 0.055 & 0.629 & 0.026 \\
\hline 20 & 0.082 & 0.392 & 0.120 & 0.094 & -0.014 & 0.120 & 0.723 & 0.047 \\
\hline 23 & 0.119 & 0.352 & 0.124 & 0.065 & 0.095 & 0.055 & 0.711 & 0.174 \\
\hline 28 & 0.059 & 0.258 & 0.018 & 0.114 & -0.037 & 0.127 & 0.574 & 0.076 \\
\hline 37 & 0.032 & 0.131 & 0.209 & 0.142 & 0.099 & 0.098 & 0.093 & 0.776 \\
\hline 38 & 0.093 & 0.205 & 0.133 & 0.137 & 0.105 & 0.086 & 0.029 & 0.821 \\
\hline 39 & 0.158 & 0.054 & 0.200 & 0.152 & 0.051 & 0.137 & 0.166 & 0.703 \\
\hline Eigenvalues & 12.19 & 3.83 & 3.28 & 2.1 & 1.73 & 1.44 & 1.35 & 1.18 \\
\hline
\end{tabular}


Table 3 - Means, standard deviations, and internal consistency for the instrument, by factor.

\begin{tabular}{|c|c|c|c|c|c|}
\hline Factor & Name of factor & Items & Mean & SD & Alpha \\
\hline 1 & Financial stressors & $2,10,11,12,13,14,15$ & 1.25 & 1.1 & 0.92 \\
\hline 2 & Working environment stressors & $18,19,21,22,24,25,26,27$ & 0.98 & 0.87 & 0.86 \\
\hline 3 & Cognitive and behavioral stressors & $40,41,42,43,44,45,46$ & 1.78 & 1.05 & 0.89 \\
\hline 4 & Family environment stressors & $4,5,6,7,8$ & 0.98 & 0.88 & 0.82 \\
\hline 5 & Health status stressors & $29,31,3336$ & 1.05 & 1.05 & 0.84 \\
\hline 6 & Stressors related to conditions for relaxation & $30,32,34,35$ & 1.54 & 1.23 & 0.88 \\
\hline 7 & Workload-related stressors & $17,20,23,28$ & 1.25 & 0.92 & 0.81 \\
\hline 8 & Social relationship stressors & $37,38,39$ & 0.64 & 0.95 & 0.79 \\
\hline
\end{tabular}

$\mathrm{SD}=$ standard deviation.

Table 4 - Adult Stressors Inventory (ASI) items with factor loadings.

\begin{tabular}{|c|c|c|}
\hline Item & Factor loading & Statement \\
\hline 2 & 0.552 & My family is having problems... \\
\hline 4 & 0.780 & My relationship with my relatives... \\
\hline 5 & 0.736 & In general, the relationships between the members of my family... \\
\hline 6 & 0.595 & Lots of things have been changing... \\
\hline 7 & 0.789 & There are a lot of issues and disagreements... \\
\hline 8 & 0.660 & I have had to sort out... \\
\hline 10 & 0.864 & It's very difficult to manage... \\
\hline 11 & 0.774 & My income... \\
\hline 12 & 0.826 & My finances are... \\
\hline 13 & 0.882 & I'm unable to pay... \\
\hline 14 & 0.841 & My money isn't... \\
\hline 15 & 0.702 & I really want to buy... \\
\hline 17 & 0.629 & The pressure at work... \\
\hline 18 & 0.732 & There is a lot of unfair... \\
\hline 19 & 0.757 & The atmosphere at work... \\
\hline 20 & 0.723 & At work they have assigned me... \\
\hline 21 & 0.661 & There's a competitive atmosphere... \\
\hline 22 & 0.641 & At work I don't have... \\
\hline 23 & 0.711 & At work I have to... \\
\hline 24 & 0.526 & My work is very... \\
\hline 25 & 0.697 & The relationship with my bosses... \\
\hline 26 & 0.619 & The relationship with my colleagues... \\
\hline 27 & 0.723 & There's a general sense of demotivation... \\
\hline 28 & 0.574 & My working hours are... \\
\hline 29 & 0.844 & I'm worried about my... \\
\hline 30 & 0.757 & I do sleep, but I can't... \\
\hline 31 & 0.839 & My health has... \\
\hline 32 & 0.838 & I'm not sleeping... \\
\hline 33 & 0.562 & I have pain that... \\
\hline 34 & 0.637 & I have been feeling... \\
\hline 35 & 0.758 & I've been having problems sleeping... \\
\hline 36 & 0.794 & I have a health problem that... \\
\hline 37 & 0.776 & My relationship with my friends... \\
\hline 38 & 0.821 & I've felt a lack of friends to... \\
\hline 39 & 0.703 & I have no social... \\
\hline 40 & 0.711 & I keep going over problems in my mind... \\
\hline 41 & 0.737 & I get irritated very... \\
\hline 42 & 0.57 & My personal life is... \\
\hline 43 & 0.567 & In my life I have to... \\
\hline 44 & 0.688 & I don't have the patience to... \\
\hline 45 & 0.723 & I always feel... \\
\hline 46 & 0.649 & I have been very worried about... \\
\hline
\end{tabular}


Stress is a response to the fact that the demands of a person's environment exceed their ability to meet them and it is known that this response varies from one individual to another. This variation is a function of factors related to the degree of perceived impact of the stressor on each person, of characteristics of the stimulus, and of the organism's ability to deal with the situation, ${ }^{15,16}$ achieving allostasis. ${ }^{13,14}$ This was taken into account in development of the ASI, through the nature of the items included and the response scale that included the magnitude of the problems described in each statement and the respondent's ability to deal them. This offers the flexibility needed to respect interindividual differences in response to stress. Lack of a method for gauging the intensity of a stressor in instruments designed to evaluate them is one of the major criticisms of the Holmes scale $\mathrm{e}^{22,23}$ and it is believed that the ASI can overcome this problem.

The sample used was characterized as diverse, in terms of sex, phase of lifecycle, ${ }^{36}$ marital status, and educational level and this social and demographic diversity enabled a test field to be assembled that characterizes the interindividual differences that interfere in the response to stressors, ${ }^{13,15,16,38,42,44}$ so that they would have an appropriate impact on the validation process.

Two successive exploratory factor analyses led to exclusion of items with low factor loadings (less than 0.49 ) and resulted in a final version of the ASI with 42 items and with a high degree of reliability. Cronbach's alpha was 0.94 for the full 42 -item scale, and Cronbach's alpha values for the factors varied from 0.8 to $0.9 .37,40$

The final factor analysis identified eight factors with Eigenvalues greater than 1 that together explained 64.5\% of the instrument's total variance. These eight factors each exhibited unity of themes that echo the literature on stress and stressors and reflect the initial constructs formulated when developing the instrument. The majority of the items in these factors had loadings greater than 0.65 .

Factors 1 (Financial stressors) and 4 (Family environment stressors) comprise statements that portray day-to-day situations like those defined as stressors in the literature ${ }^{42}$ and which constitute life events that effect acute changes, forcing the organism to adjust. The impact of these demands will depend on their magnitude and predictability and these in turn are dependent on psychosocial factors such as gender, income, social class, professional role, and other variables that were considered when composing the sample.

The literature that analyzes the relationship between stress and physical and mental diseases ${ }^{8-12}$ provides support for factor 5 (Health status stressors), comprising statements that portray concerns related to the respondent's health. In turn, factor 3 (Cognitive and behavioral stressors), comprising statements that relate to ruminative thoughts, anxiety, and behavior that is inappropriate for avoiding stress, is supported by studies that consider the importance of metacognition, ${ }^{17,19}$ of emotional intelligence, ${ }^{21}$ and of cognitive schemes ${ }^{43,45}$ in generation and maintenance of stress.

The rhythm of modern life increasingly stimulates productivity and competitivity. In a classic study, Friedman and Rosenman ${ }^{46}$ define a behavior pattern they called Type A, which is made up of a series of characteristics associated with competitivity and urgency in everyday activities and which predisposes people to stress and to heart problems. The characteristics of Type A behavior are manifest in factor 6 (Stressors related to conditions for relaxation), not necessarily as behavioral characteristics, but as the stressful conditions they provoke. It is interesting to observe that this factor was not part of the initial construct underlying the inventory,

Table 5 - Means and standard deviations of scores for overall Adult Stressors Inventory (ASI) and its factors, for each quartile of the Perceived Stress Scale (PPS).

\begin{tabular}{|c|c|c|c|c|c|c|c|c|c|c|}
\hline \multirow[b]{2}{*}{ Factors } & \multicolumn{2}{|c|}{$\begin{array}{c}\text { Quartile } 1 \\
\mathbf{N}=130\end{array}$} & \multicolumn{2}{|c|}{$\begin{array}{c}\text { Quartile } 2 \\
\mathbf{N}=105\end{array}$} & \multicolumn{2}{|c|}{$\begin{array}{c}\text { Quartile } 3 \\
N=113\end{array}$} & \multicolumn{2}{|c|}{$\begin{array}{c}\text { Quartile } 4 \\
\mathbf{N}=102\end{array}$} & \multicolumn{2}{|c|}{$\begin{array}{l}\text { All cases } \\
N=450\end{array}$} \\
\hline & Mean & SD & Mean & SD & Mean & SD & Mean & SD & Mean & SD \\
\hline Mean overall ASI score & 0.76 & 0.45 & 1.09 & 0.58 & 1.38 & 0.6 & 1.9 & 0.61 & 1.25 & 0.7 \\
\hline Financial stressors & 0.68 & 0.76 & 1.04 & 0.94 & 1.54 & 1.19 & 1.88 & 1.11 & 1.25 & 1.1 \\
\hline Working environment stressors & 0.68 & 0.64 & 0.93 & 0.88 & 1.01 & 0.88 & 1.41 & 0.95 & 0.99 & 0.87 \\
\hline Cognitive and behavioral stressors & 0.96 & 0.66 & 1.47 & 0.78 & 2.02 & 0.89 & 2.88 & 0.79 & 1.78 & 1.05 \\
\hline Family environment stressors & 0.64 & 0.63 & 0.9 & 0.85 & 1.01 & 0.81 & 1.47 & 1.05 & 0.98 & 0.88 \\
\hline Health status stressors & 0.65 & 0.83 & 0.92 & 0.87 & 1.12 & 1.06 & 1.68 & 1.12 & 1.05 & 1.05 \\
\hline Stressors related to conditions for relaxation & 0.92 & 0.92 & 1.35 & 1.12 & 1.78 & 1.26 & 2.35 & 1.15 & 1.56 & 1.23 \\
\hline Workload-related stressors & 1.19 & 1.01 & 1.46 & 1.03 & 1.61 & 1.2 & 2.07 & 1.2 & 1.56 & 1.15 \\
\hline Social relationship stressors & 0.29 & 0.5 & 0.59 & 0.91 & 0.63 & 0.89 & 1.15 & 1.13 & 0.64 & 0.95 \\
\hline
\end{tabular}

$\mathrm{SD}=$ standard deviation. 
but was revealed during the factor analysis, standing out as an independent factor.

Work as a source of stress was split across two different factors, factor 2 (Working environment stressors) and factor 7 (Workload-related stressors). In the initial design for the instrument, the subject of work was restricted to a single group, but factor analysis split it into two groups, one comprising subjects related to human relations at work and another related to workload. This division finds support in the literature, which identifies factors related to organization of work, socioprofessional relationships, and working conditions as sources of stress. ${ }^{47,48}$ Research also shows that work in which demands and pressure exceed the worker's knowledge and capacity tends to be a major stress producer, particularly when combined with little opportunity for decision making, a low level of autonomy, and little support from colleagues. ${ }^{49,50}$

Factor 8 (Social relationship stressors), contains statements on the quality of interpersonal relationships. This is in line with factors of social loneliness identified in the literature as predisposing to stress. ${ }^{51}$ The factors identified by factor analysis are adequately correlated with the literature on stress and with the initial construct, fulfilling the validation criteria. ${ }^{52}$

The analysis of validity by hypothesis considered that a psychological instrument should be capable of discriminating or predicting a criterion external to itself. ${ }^{52}$ Analysis of the results of the ASI in comparison with those of groups formed by PSS results quartiles revealed that the higher the quartile to which the participant was allocated, the higher his or her perception of stress and, consequently, the greater the magnitude of perception of the stressors listed in the ASI. This comparison was confirmed by inter-quartile ANOVA that demonstrated differences significant to $p \leq 0.05$ between the mean ASI scores in each PSS quartile, confirming the validation hypothesis established previously.

Finally, analysis of the means and standard deviations of the ASI results by PSS quartiles demonstrated a progression in ASI results as the PSS results for perceived stress increase, indicating that, in addition to its ability to identify the area provoking stress, the ASI also appears to be capable of identifying the magnitude of each area's contribution to stress. It was therefore observed that basic properties such as validity and reliability or trustworthiness are fulfilled by the ASI. 44

These data indicate that the ASI fulfills the criterion of evaluating the intensity of the stress-inducing stimulus. This demonstrates a positive improvement over the Holmes scale, since it appears that the ASI is adequately evaluating variability of perception of stress-inducing stimuli.
With regard to comparisons between ASI and other instruments for assessment of stress or stressors, the ASI offers advantages over other available instruments, since it covers eight domains of stress generation with good psychometric properties. For example, instruments have been developed to evaluate stress in nursing students, ${ }^{53}$ in teachers in the context of employment, ${ }^{30}$ and in production-line workers, ${ }^{28}$ among others, but all of these address specific scenarios and do not extend to a broader spectrum of stressors.

Two options for evaluation of a broader spectrum of stressful events do exist. The Impact of Event Scale has been translated and adapted for Brazil ${ }^{54}$ and a stressful life event reporting questionnaire was developed for the Pró-Saúde study, ${ }^{31}$ but neither of these cover a wide spectrum of stressful areas of life, unlike the ASI. Finally, the most widely used instrument in Brazil for stress assessment, the ISSL - Adult Stress Symptoms Inventory, ${ }^{25}$ is an adequate instrument for identifying stress, but it does not enable identification of the stressors causing stress.

\section{Conclusions}

The Adult Stressors Inventory (ASI), demonstrated adequate internal consistency and factor analysis revealed that it was coherent with the initial constructs, which appears to denote that the newly-developed instrument has adequate construct validity and discriminatory validity. It was observed that the ASI has good psychometric capacities when compared with the results of the PSS for the same sample. The sample employed covered the many different variables that can interfere in the stress process, proving to be consistent with the literature.

One interesting point observed during validation of the instrument is the clear relationship between the factors identified by factor analysis and what is stated in the Brazilian and international literature on stress, and also with the original construct.

One limitation of this study is related to analysis of data by sex and age group, which would require a sample that had been planned in advance and was more balanced in this respect.

It would be interesting to expand the sample in order to test whether the instrument discriminates by the variables sex, age, marital status, and profession. Such an analysis could show whether the ASI scores exhibit differences associated with social and demographic factors and could be used to derive normative data for interpretation of results.

This study's primary contribution lies in the possibility of making an instrument available for objectively 
understanding stressors that could be responsible for generating and maintaining stress. Understanding the source of stress provides a basis for development and application of strategies focused on its treatment.

\section{Acknowledgements}

The present study received funding from Universidade Paulista (UNIP) throuth an individual research program (Programa Individual de Pesquisa para Docentes). I am grateful to the undergraduate Psychology students who helped with data collection.

\section{Disclosure}

No conflicts of interest declared concerning the publication of this article.

\section{References}

1. Selye H. Stress and the general adaptation syndrome. $\mathrm{Br}$ Med J. 1950;1:1383-92.

2. Selye H. Stress: a tensão da vida. São Paulo: Ibrasa; 1959.

3. Oken BS, Chamine I, Wakeland W. A systems approach to stress, stressors and resilience in humans. Behav Brain Res. 2015;282:144-54.

4. Franklin TB, Saab BJ, Mansuy IM. Neural mechanisms of stress, resilience and vulnerability. Neuron. 2012;75:747-61.

5. Pfau ML, Russo SJ. Peripheral and central mechanisms of stress resilience. Neurobiol Stress. 2015;1:66-79.

6. Munzel T, Daiber A. Environmental stressors and their impact on health and disease with focus on oxidative stress. Antioxid Redox Signal. 2018;28:735-40.

7. Lipp MEN, organizador. Mecanismos neuropsicofisiológicos do stress: teoria a aplicações clínicas. São Paulo: Casa do Psicólogo; 2003.

8. Taborda MVV, Weber MB, Freitas ES. Avaliação da prevalência de sofrimento psíquico em pacientes com dermatoses do espectro dos transtornos psicocutâneos. An Bras Dermatol. 2005;80:3514.

9. Munzel T, Sørensen, M, Gori T, Schmidt FP, Rao X, Brook J, et. al. Environmental stressors and cardio-metabolic disease: part I - epidemiologic evidence supporting a role for noise and air pollution and effects of mitigation strategies. Eur Heart J. 2017;38:550-6.

10. Wottrich SH, Ávila CM, Machado CC, Goldmeier S, Dillenburg D, Kuhl CP, et. al. Gênero e manifestação de stress em hipertensos. Estud Psicol. 2011;28:27-34.

11. Homann D, Stefanello JMF, Góes SM, Breda CA, Paiva ES, Leite N. Percepção de estresse e sintomas depressivos: funcionalidade e impacto na qualidade de vida em mulheres com fibromialgia. Rev Bras Reumatol. 2012;52:319-30.

12. Jansen B. Cómo adaptarse a los cambios en la sociedad y en el mundo del trabajo: una nueva estrategia comunitaria de salud y seguridad (2002-2006). Bruselas: Comisión de las Comunidades Europeas; 2006.

13. Sousa MBC, Silva HPA, Galvão-Coelho NL. Resposta ao estresse: I. homeostase e teoria da alostase. Estud Psicol. 2015;20:2-11.

14. McEwen BS. Physiology and neurobiology of stress and adaptation: central role of the brain. Physiol Rev. 2007;87:873-904.

15. Conway CC, Slavich GM, Hammen C. Dysfunctional attitudes and affective responses to daily stressors: separating cognitive, genetic, and clinical influences on stress reactivity. Cognit Ther Res. 2015;39:366-77.
16. Bettis $\mathrm{AH}$, Forehand R, McKee L, Dunbar JP, Watson $\mathrm{KH}$, Compas BE. Testing specificity: associations of stress and coping with symptoms of anxiety and depression in youth. J Child Fam Stud. 2016;25:949-58.

17. Sprague J, Verona E, Kalkhoff, W, Kilmer A. Moderators and mediators of the stress-aggression relationship: executive function and state anger. Emotion. 2011;11:61-3.

18. Wells A, King P. Metacognitive therapy for generalized anxiety disorder: an open trial. J Behav Ther Exp Psychiatry. 2006;37:20612.

19. Spada MM, Nikcevic AV, Moneta GB, Wells A. Metacognition, perceived stress, and negative emotion. Pers Individ Dif. 2008;44:1172-81.

20. Golemam D. Inteligência emocional: a teoria revolucionária que redefiniu o que é ser inteligente. Rio de Janeiro: Objetiva; 1996. (Translation: Marcos Santarrita).

21. Armstrong AR, Galligan RF, Critchley CR. Emotional intelligence and psychological resilience to negative life events. Pers Individ Dif. 2011;51:331-6.

22. Dohrenwend BP. Inventorying stressful life events as risk factors for psychopathology: toward resolution of the problem of intracategory variability. Psychol Bull. 2006;132:477-95.

23. Mongentale AP, Vizzotto MM. Estresse e reajustamento social em auxiliares de enfermagem. Psicol Inf. 2011;15:83-98.

24. Scully JA, Tosi H, Banning K. Life event checklists: revisiting the social readjustment rating scale after 30 years. Educ Psychol Meas. 2000;60:864-76.

25. Lipp MEN. Manual do inventário de sintomas de stress para adultos de Lipp (ISSL). 3th ed. São Paulo: Casa do Psicólogo; 2005.

26. Cohen S, Kamarck T, Mermelstein R. A global measure of perceived stress. J Health Soc Behav. 1983;24:385-96.

27. Reis RS, Hino AAF, Añez CRR. Perceived Stress Scale: reliability and validity study in Brazil. J Health Psychol. 2010;15:107-14.

28. Cusatis Neto R. Construção e validação da escala de estressores ocupacionais da linha de produção [thesis]. Campinas: Pontifícia Universidade Católica de Campinas; 2007.

29. Anjos DR, Silva EA, Falqueiro EJA; Freitas PMP, Peres VPM, Massruhá VC et. al. Estresse: fatores desencadeantes, identificação e avaliação de sinais e sintomas no enfermeiro atuante em UTI neonatal. J Health Sci Inst. 2008;26:426-31.

30. Figueroa NL, Schufer M, Muiños R, Marro C, Coria EA. Um instrumento para a avaliação de estressores psicossociais no contexto de emprego. Psicol Reflex Crit. 2001;14:653-59.

31. Lopes CS, Faerstein F. Confiabilidade do relato de eventos de vida estressantes em um questionário autopreenchido: Estudo PróSaúde. Braz J Psychiatry. 2001;23:126-33.

32. Marshall AC, Cooper NR, Segrave R, Geeraert N. The effects of long-term stress exposure on aging cognition: a behavioral and EEG investigation. Neurobiol Aging. 2015;36:2136-44.

33. Turato ER. Tratado da metodologia da pesquisa clínico-qualitativa. $2^{a}$ ed. Petrópolis: Vozes; 2003.

34. Bocchi SCM, Juliani CMCM, Spiri WC. Métodos qualitativos de pesquisa: uma tentativa de desmistificar a sua compreensão. Botucatu: Departamento de Enfermagem, Faculdade de Medicina, UNESP Botucatu; 2008.

35. Bardin L. Análise de conteúdo. Lisboa: Edições 70; 1977.

36. Griffa MC. Chaves para a psicologia do desenvolvimento. São Paulo: Paulinas; 2001. Vol II.

37. Primi R. Psicometria: fundamentos matemáticos da Teoria Clássica dos Testes. Aval Psicol. 2012;11:297-307.

38. Pasquali L. Psicometria. Rev Esc Enferm USP. 2009;43:992-9.

39. Pasquali L. Técnicas de exame psicológico: Vol. I - Fundamentos das técnicas de exame psicológico. São Paulo: Casa do Psicólogo; 2001.

40. Maroco J, Garcia-Marques T. Qual a fiabilidade do alfa de Cronbach? Questões antigas e soluções modernas? Labor Psicol. 2006; 4:65-90.

41. Hair Jr JF, Anderson RE, Tatham RL, Black WC. Análise multivariada de dados. $5^{a}$ ed. Porto Alegre: Bookman; 2005.

42. Carr D, Umberson D. The social psychology of stress, health, and coping. Handbook of social psychology. Amsterdam: Springer: 2013.

43. Benzoni PE. Stress crônico e temas de vida: uma proposta cognitivo-comportamental para conceitualização [thesis]. Campinas: Pontifícia Universidade Católica de Campinas; 2008.

44. Alexandre NMC, Gallasch CH, Lima MHM, Rodrigues RCM. A confiabilidade no desenvolvimento e avaliação de instrumentos de medida na área da saúde. Rev Eletr Enf. 2013;15:802-9. 
45. Benzoni PE. Estilos parentais e stress dos filhos: quando a combinação desses fatores pode levar ao desenvolvimento de transtornos psicológicos. In: Lipp MEN, editor. Stress em crianças e adolescentes. Campinas: Papirus; 2014. p. 165-79.

46. Friedman M, Rosenman RH. Type A behavior and your heart. New York: Knopf; 1974.

47. Corrêa AS, Menezes JRM. Estresse e trabalho [monograph]. Campo Grande: Pós-Graduação Lato Sensu, Sociedade Universitária Estácio de Sá; 2002.

48. Benzoni PE, Barato $\mathrm{C}$, Marchesin MA, Inocente MM. Afastamento do trabalho e crise do capital: a incapacidade refletindo 0 contexto. SER Social. 2016;18:540-61.

49. Leka S, Griffiths A, Cox T. Work organization and stress: systematic problem approaches for employers, managers and trade union representatives. Geneva: World Health Organization; 2003. Vol. 3.

50. Karasek RA. Job demands, job decision latitude, and mental strain: implications for job redesign. Adm Sci Q. 1979;24:285908.

51. Hawkley LC, Hughes ME, Waite LJ, Masi CM, Thisted RA. Cacioppo JT. From social structural factors to perceptions of relationship quality and loneliness: the Chicago health, aging, and social relations study. J Gerontol B Psychol Sci Soc Sci. 2008;63:37584.

52. Pasquali L. Psicometria: teoria dos testes na psicologia e educação. Petrópolis: Vozes; 2003.

53. Costa ALS, Polak C. Construção e validação de instrumento para avaliação de estresse em estudantes de Enfermagem (AEEE). Rev Esc Enferm USP. 2009;43:1017-26

54. Silva $A C O$, Nardi $A E$, Horowitz $M$. Versão brasileira da Impact of Event Scale (IES): tradução e adaptação transcultural. Rev Psiquiatr Rio Gd Sul. 2010;32:86-93.

\section{Correspondence:}

Paulo Eduardo Benzoni

Rua Siró Kaku, 42/81, Jardim Botânico

14021-614 - Ribeirão Preto, SP - Brazil

Tel. : +55 (16) 34217261, +55 (16) 991340649

E-mail: paulo.benzoni@docente.unip.br 